\title{
Herophilos, the great anatomist of antiquity*
}

\author{
Rafael Romero Reverón* \\ Human Anatomy Department, 7.M. Vargas School of Medicine, Universidad Central de Venezuela, Caracas, Venezuela
}

\begin{abstract}
Herophilos (ca. 330 to ca. 260 B.C.) was a Greek physician and precursor in learning and teaching of human anatomy through systematic anatomical dissections who made extraordinary anatomical discoveries. He developed the theory of using the pulse as a form of diagnosis and introduced the use of experimental method to medicine.
\end{abstract}

Keywords: dissection; Herophilos, human anatomy

Anatomy 2015;9(2):108-111 (C2015 Turkish Society of Anatomy and Clinical Anatomy (TSACA)

\section{Introduction}

The city of Alexandria, Egypt, was the world center of learning and scholarship in the 3rd century B.C. It was founded by Alexander the Great in 332 B.C. and established by the mighty Ptolemaio Pharoahs. This city was home to many prominent philosophers and medical practitioners of that time. ${ }^{[1]}$

Although there are very few historical documents, it may fairly be stated that the Alexandrian physicians were the first in the medical tradition to perform systematic dissections of human cadavers.

The knowledge of human anatomy (from the Greek word $\alpha v \alpha \tau o \mu$ í $\alpha$ (anatomē), which means dissection) constitutes an essential pillar in the broad and complex field of medicine. Among the main contributions in the field of learning and teaching of human anatomical dissections, those made by Herophilos of the school of anatomy in Alexandria stand out. ${ }^{[2]}$ The cultural, social, intellectual and political conditions of Alexandria in the third century B.C. provided Herophilos with opportunities to dissect human cadavers. He was thus able to make an unprecedented number of anatomical discoveries and accompany them with precise descriptions (Figure 1). ${ }^{[3]}$

The objective of this paper is to make a review of Herophilos' contribution to of human anatomy. Little is known about Herophilos' life. From secondary sources, such as the physician Galen, the writer Celsus and the theologian Tertullian in the 2nd century A.D., Herophilos and his works are known. About 250 years after the death of Herophilos, Celsus and later Tertullian blamed him to have performed vivisection on condemned criminals awarded to Herophilos by the rulers of Alexandria, but such accusations remain speculative. ${ }^{[2,4,5]}$

\section{Background}

Aristotle dissected animals in the 4th century B.C., and there were also dissections by other Greek physicians in previous centuries and later on by Galen in the 2 nd century, but Herophilos' work drew widespread praise.

It is believed that Herophilos was born in Chalcedon, currently Kadikoy, a settlement on Bosphorus, Turkey, about the year 335 B.C. ${ }^{[6,7]}$ His name comes from the ancient Greek word pópı $\lambda$ os, later sometimes Latinized as Herophilus.

We have no knowledge of his childhood. He was trained as a physician with Praxagoras and Crisipus of Cnido, physicians and anatomists who taught in the medical school of Greek island of Cos. After his medical training, Herophilos went to live in Alexandria, where he

\footnotetext{
*Numerary Member of the Venezuelan Society of the History of Medicine; Member of the International Society of the History of Medicine, Member of the American Association of the History of Medicine; Medical Doctor, Specialist in Orthopedic Trauma Surgery at the Centro Médico Docente La Trinidad and Urológico San Román, Caracas, Venezuela
} 
learned and practiced human anatomy dissection and

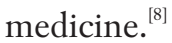

Systematic dissections of human cadavers started in Alexandria in the third century B.C. and for about 30 years of Herophilos' life, the prohibition on human dissections was removed, initiating this medical practice. He and some of his colleagues and disciples had the exclusive opportunity to perform human dissections, a procedure that was not tolerable anywhere else at the time. ${ }^{[9]}$ After this period, human dissection was banned and not permitted again for about 1,800 years until it began to be practiced again during the 14th century A.D. Herophilos was among the first physicians to perform anatomical dissections in public, dissected more than 600 human cadavers and being among the first to compare human and animal morphology. His dissections provided unprecedented knowledge of how the human body and its organs worked. ${ }^{[2,7]}$ He created terms to systematically describe the objects of study, as opposed to the use of "natural names", named them for the first time and established anatomical nomenclature so that there was some uniformity for study and description.

\section{His anatomical discoveries of the nervous system}

Herophilos made outstanding anatomical discoveries in human cadavers: for example, he distinguished the brain from the cerebellum, and described the brain as the seat of intelligence, ${ }^{[10]}$ contrary to the beliefs of his contemporaries.

He recognized and studied the internal surface of the skull and the cranial sutures. Herophilos described the lower brainstem and spinal cord as one structure he referred to as "spinal marrow", and also identified and described several brain structures, some of which still have his name, such as the concavity on the internal surface of the occipital bone, in which lodges the posterior confluent of the cranial venous sinuses, known as the Herophilos' press (torcular Herophili). ${ }^{[1]]}$ The three membranes of the brain were also recognized by Herophilos and designated as "chorioid" because they resembled the chorionic envelope surrounding the fetus. On the vision system, Herophilos explored the optic nerve and described the sclerotic ring, the retina, and the choroid coat. ${ }^{[2,7]}$ He studied the encephalon by dissecting human cadavers and carrying out investigations with animals, describing the choroid plexus, the meninges, and the fourth ventricle. $\mathrm{He}$ discovered that nerves originated in the brain, was the first to distinguish nerves from tendons and observed the difference between the motor and sensory nerves. ${ }^{[1,1]}$ Herophilos also described at least six cranial nerves and named them the optic, oculomotor, trigeminal, facial, auditory and hypoglossal nerves, and pointed out that

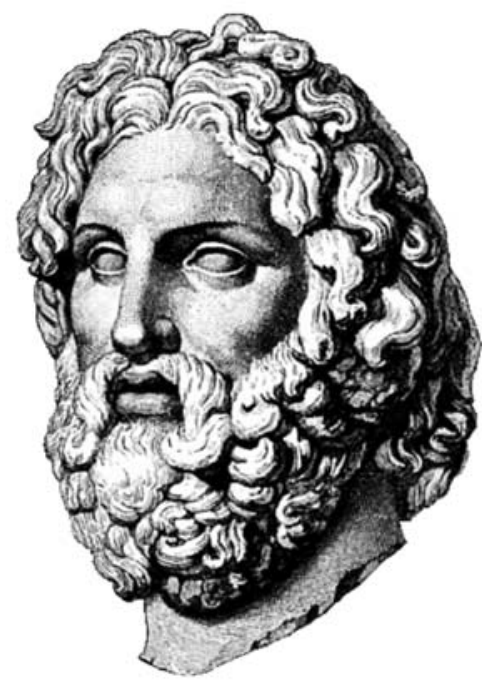

Figure 1. Herophilos (ca. 330 to ca. 260 B.C.) from How human experimentation worksworks? ${ }^{[3]}$

damage to motor nerves produced paralysis. ${ }^{[12]}$ Herophilos named the styloid process of the skull. ${ }^{[13]}$

\section{His anatomical discoveries on the digestive system}

Herophilos studied the liver extensively and described and named the duodenum, the ileum and colon, performed the first research of the pancreas. ${ }^{[14]} \mathrm{He}$ described the submandibular glands and the parotid gland and he also described and gave his name to the hyoid bone. ${ }^{[15,16]}$ Herophilos knew the vessels of the mesentery, and showed that they did not go to vena portae. Herophilos also noted the existence of the lymphatic system but did not rule orut its function.

\section{His anatomical discoveries on the cardiovascular system}

Herophilos established the distinction between arteries and veins and confirmed that the arteries had thicker walls than the veins ${ }^{[6,12]}$ and maintained the idea that arteries carried blood rather than air. ${ }^{[16,17]} \mathrm{He}$ described the pulmonary artery which he denominated arterious vein and also described the pulmonary vein. ${ }^{[18]}$ His mentor Praxagoras' misconception that the pulse was not associated with the heart beat was refuted by Herophilos, ${ }^{[19]}$ who pointed out the importance of the pulse, establishing the synchronicity of pulse and heart beats. He sustained that the pulse was not a natural faculty of the arteries, but was derived from the heart, and differentiated the pulse as not simply quantitative but also qualitative of palpitations, tremors and spasms which are muscular in origin. ${ }^{[9,17.18]} \mathrm{He}$ was the first 
to point out that the pulse could be used as an indicator of disease, believing that artery pulsations were involuntary, as a result of the dilatation and contraction of arteries due to impulses sent by the heart. He observed the pulse of the arteries and developed measuring standards, using a water clock and made important contributions to medicine by developing the theory of diagnosing through the pulse. ${ }^{[19]}$ Herophilos is considered for his researches as one of the precursors of cardiology. He described the anatomy of the heart valves. ${ }^{[20]} \mathrm{He}$ also described the respiratory movements.

\section{His anatomical discoveries on the reproductive system}

On the male reproductive system, Herophilos described the epididymis, the prostate gland, and identified the various parts of the spermatic duct. ${ }^{[6]}$ He recognized that the testicles produced spermatozoa. On the female reproductive system, Herophilos described the ovaries, the uterine tubes, and the uterus, ${ }^{[21]}$ showing that the latter was attached by the broad ligament and thus not mobile in the body as had been previously thought. He described the phases and duration of pregnancy as well as causes for difficult childbirth. Herophilos also described and explained the causes of uterus prolapsus and rightly held that only the cervix, and not the entire uterus, can protrude. He was also interested in the relationship between menstruation and general health.

\section{Herophilos' medical practice}

In the field of medical treatments, Herophilos was a sponsor of Plato's dogmatic doctrine, which gave preference to reason above experience, classifying all diseases based on the theory of the accumulation of humors and maintained the ancient doctrine of the four humors as the basis for treatment. ${ }^{[7,8]}$ Herophilos revised the humor theory of Hippocrates. In his own theory, he argued against the notion that the veins were filled with a blend of blood, water and air; rather he showed, through his dissections that it was pure blood in the veins. Thus, he used bloodletting and purging to evacuate the unwanted humors. ${ }^{[8]}$ To Herophilos, an imbalance of the four humors triggered all diseases.

The cardiocentric thesis enjoyed great success well beyond Aristotles and Praxagoras, and among others Greek physicians and philosophers, ${ }^{[10]}$ but Herophilos rejected cardiocentric thesis and returned to Hippocraticencephalocentrism supported in his anatomical research on the configuration and function of the brain. ${ }^{[2]} \mathrm{He}$ was also one of the first doctors who recommended the habits of proper diet and exercise. ${ }^{[7,17]}$ For
Herophilos, prognosis was derived from the symptoms, and for this reason, symptoms should be clearly recognized. Herophilos acquired great prestige, both as a practitioner and as a teacher of human anatomy. He considered there were limits to medical activity, arguing that an accomplished physician can differentiate what is possible from what is not possible. It is attributed to Herophilos to have said "When bealth is absent, wisdom cannot reveal itself, art cannot manifest, strength cannot fight, wealth becomes useless, and intelligence cannot be applied" ${ }^{[2,7,8]}$ Herophilos is thought to be one of the founders of the scientific method. He had introduced the experimental method to medicine, for he considered it essential to found knowledge on empirical bases. For that, he was criticized by Galen for whom the experimental method contradicted rationality.

\section{Discussion}

Herophilos was a precursor in the learning and teaching of human anatomy through systematic dissections of human cadavers that is why he is considered the 'Father of Human Anatomy ${ }^{[6,21,22]}$ It appears that he wrote three treatises devoted to anatomy, one to midwifery, two each to the study of the pulse and to therapeutics, one to ophthalmology and one to dietetics. ${ }^{[1,7]}$ None of his works have been preserved, they disappeared with the destruction of the library of Alexandria. ${ }^{[15,23]}$

His teachings and research were complemented and enhanced by his disciple Erasistratus, ${ }^{[1,24,25]}$ but after Herophilos' death, about the year 280 B.C, his followers got caught up for centuries in unfriendly and needless polemics, with the following decline in the medical application of his teachings and research in the field of human anatomy studies. ${ }^{[7,17,26]}$

\section{References}

1. Pearce J. The neuroanatomy of Herophilus. Eur Neurol 2013;69: 292-5.

2. Magner L. A history of medicine. 2nd ed. Boca Raton: Taylor and Francis; 2005. p. 106-13.

3. How human experimentation works? http://holykaw.alltop.com/ how-human-experimentation-works

4. Scarborough J. Celsus on human vivisection at Ptolemaic Alexandria. Clio Med 1976;11:25-38.

5. Sinha DN. Ancient human cadaveric dissection. Personal communique. National Journal of Clinical Anatomy 2015;4:53-7.

6. Bay NS, Bay BH. Greek anatomist Herophilus: the father of anatomy. Anat Cell Biol 2010;43:280-3.

7. Sigerist HE. A History of medicine. Vol. II. Early Greek, Hindu, and Persian Medicine 1961. New York: Oxford University Press. p. 2626.

8. Dobson J. Herophilus of Alexandria. Proc R Soc Med 1925;18:19-32. 
9. Moon K, Filis AK, Cohen AR. The birth and evolution of neuroscience through cadaveric dissection. Neurosurgery 2010;67:799809.

10. Crivellato E, Ribatti D. Soul, mind, brain: Greek philosophy and the birth of neuroscience. Brain Res Bull 2007;71:327-36.

11. Tubbs RS, Oakes WJ. 2002. Letter to the Editor. Neuroanatomy 2002;1:14

12. Reverón RR. Herophilus and Erasistratus, pioneers of human anatomical dissection. Vesalius 2014;20:55-8.

13. Persaud TVN. Early history of human anatomy: from antiquity to the beginning of the modern era. Springfield: Charles C. Thomas; 1984.

14. Acar F, Naderi S, Guvencer M, Ture U, Arda M. Herophilus of Chalcedeon: pioneer in neuroscience. Neurosurgery 2005;56:861-7.

15. Strkalj G, Chorn D. Herophilus of Chalcedon and the practice of dissection in Hellenistic Alexandria. S Afr Med J 2008;98:86-9.

16. Potter P. Herophilus of Chalcedon: an assessment of his place in the history of anatomy. Bull Hist Med 1976;50:45-60.

17. von Staden H. Herophilus: the art of medicine in early Alexandria: edition, translation, and essays. Cambridge: Cambridge University Press; 1989.
18. Harris CRS. The heart and the vascular system in ancient Greek medicine: from Alcmaeon to Galen. Oxford: Clarendon Press; 1973.

19. Khan IA, Daya SK, Gowda RM. Evolution of the theory of circulation. Int J Cardiol 2005;98:519-21.

20. Buzzi A, Doisenbant AR. Evolución histórica de la medicina. Buenos Aires: Editorial Médica Panamericana; 2008. p. 110-1.

21. Mavrodi A, Paraskevas G. Morphology of the heart associated with its function as conceived by ancient Greeks. Int J Cardiol 2014;172: 23-8.

22. Loukas M, Hanna M, Alsaiegh N, Shoja MM, Tubbs RS. Clinical anatomy as practiced by ancient Egyptians. Clin Anat 2011;24:409_ 15 .

23. Imai M. Herophilus of Chalcedon and the Hippocratic tradition in early Alexandrian medicine. Hist Sci (Tokyo) 2011;21:103-22.

24. Smith CU. The triune brain in antiquity: Plato, Aristotle, Erasistratus. J Hist Neurosci 2010;19:1-14.

25. Wiltse LL, Pait TG. Herophilus of Alexandria (325-255 B. C.). The father of anatomy. Spine (Phila Pa 1976) 1998;23:1904-14.

26. Wills A. Herophilus, Erasistratus, and the birth of neuroscience. Lancet 354:1719-20.

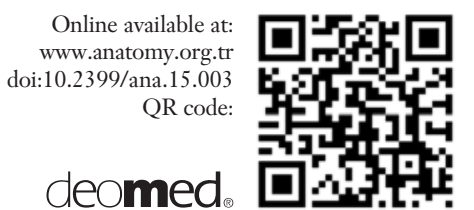

Rafael Romero Reverón, MD

Human Anatomy Department, J.M. Vargas School of Medicine, Universidad Central de Venezuela,

Caracas, Venezuela

e-mail: rafa1636@yahoo.es; RafaelRomeroReveron@yahoo.com.ve

Conflict of interest statement: No conflicts declared.

\begin{abstract}
This is an open access article distributed under the terms of the Creative Commons Attribution-NonCommercial-NoDerivs 3.0 Unported (CC BY-NCND3.0) Licence (http://creativecommons.org/licenses/by-nc-nd/3.0/) which permits unrestricted noncommercial use, distribution, and reproduction in any medium, provided the original work is properly cited. Please cite this article as: Romero RR. Herophilos, the great anatomist of antiquity. Anatomy 2015;9(2):108-111.
\end{abstract}

